\title{
PERTUMBUHAN SETEK SAMBUNG KINA (Cinchona Sp) KLON QRC AKIBAT PERBEDAAN PANJANG SETEK BATANG ATAS
}

\section{GROWTH OF GRAFTING OF Cinchona Sp CLONE QRC DUE TO DIFFERENCE OF UPPER STEM LENGTH}

\author{
Joko Santoso $^{1)}$, Yayo Fatimah ${ }^{1)}$, Merry Antralina ${ }^{1)}$, dan Dina Aryati ${ }^{2)}$ \\ ${ }^{1)}$ Fakultas Pertanian Universitas Bale Bandung \\ ${ }^{2)}$ Alumni Fakultas Pertanian Universitas Bale Bandung \\ Korespondensi : gmbg-santos@yahoo.co.id
}

Diterima 23 Maret 2016 / Disetujui 28 Juni 2016

\begin{abstract}
ABSTRAK
Penelitian yang bertujuan untuk mempelajari pengaruh variasi panjang setek terhadap pertumbuhan setek sambung kina (Cinchona $s p$ ) klon QRC telah dilaksanakan di kebun percobaan Pusat Penelitian Teh dan Kina (PPTK) Gambung, Kabupaten Bandung, dengan ketinggian kurang lebih 1300 meter di atas permukaan laut, jenis tanah Andisol, tipe iklim B menurut klasifikasi Schmidt dan Fergusson (1951) dengan curah hujan rata-rata antara 2000 $3000 \mathrm{~mm}$ per tahun dan suhu rata-rata $13,5^{\circ} \mathrm{C}-21,1^{\circ} \mathrm{C}$. Kelembaban relatif antara $68 \%$ sampai 97\%. Menggunakan Rancangan Acak Kelompok (RAK) dengan 5 perlakuan dan diulang lima kali. Jumlah tanaman per plot adalah 50 tanaman: perlakuan panjang setek terdiri dari $5 \mathrm{~cm}$, $7 \mathrm{~cm}, 9 \mathrm{~cm}, 11 \mathrm{~cm}$, dan $13 \mathrm{~cm}$. Hasil penelitian menunjukkan bahwa Panjang setek sambung atas yang berbeda memberikan pengaruh yang berbeda terhadap persentase setek hidup, panjang setek, jumlah daun, jumlah akar dan panjang akar bibit kina di pembibitan. Penggunaan setek sambung dengan panjang $7 \mathrm{~cm}$, memberikan pengaruh yang paling baik terhadap pertumbuhan bibit sambung kina (Cinchona ledgeriana Moens) di pembibitan yang ditunjukkan oleh persentase hidup, jumlah daun, tinggi bibit dan jumlah akar yang lebih tinggi dibanding perlakuan yang lain.
\end{abstract}

Kata kunci : Bibit Kina, Pertumbuhan, Setek batang atas, Setek sambung,

\begin{abstract}
The objective of this research was to evaluate the effect of variation in the length of cuttings on the growth of grafted cutting of cinchona (Cinchona Sp. ) clone QRC. The research was conducted in Gambung Experimental Garden, Research Institute for Tea and Cinchona, Bandung at 1,300 $\mathrm{m}$ above sea level, Andisol soil type with type B of climate according to the classification of Schmidt and Fergusson (1951), average of rainfall between 2,000 mm - 3,000 $\mathrm{mm}$ per year, average temperature of $13,5^{\circ} \mathrm{C}-21,1^{\circ} \mathrm{C}$, and relative humidity of $68 \%-97 \%$. The research used randomized block design (RBD) with five treatments and five replications. The treatment was length of cutting was consisted of 5, 7, 9, 11, and $13 \mathrm{~cm}$. The result showed that the different length gave a different effect on the percentage of live grafted cutting, length of grafted cutting, number of leaves, number of root as well as length of root of seedling in nursery. The used of $7 \mathrm{~cm}$ of cutting gave the best effect on the growth of grafted cinchona
\end{abstract}


seedling in nursery indicated by the percentage of live seedling which was better than other treatments.

Keywords : Cuttings scions, Grafting cuttings, Growth, Quinine Seed

\section{PENDAHULUAN}

Tanaman kina merupakan sumber devisa non migas dari sub sektor perkebunan, kulit kina merupakan bahan baku industri farmasi, dan mengandung lebih dari 20 macam senyawa alkaloida. Sampai saat ini baru 2 alkaloida yang dimanfaatkan dan mempunyai nilai ekonomi tinggi, yaitu garam kinina dan kinidina.

Hasil yang diambil dari tanaman kina adalah kulitnya yang merupakan bahan baku farmasi yang penting karena mengandung senyawa alkaloida antara lain kinina, kinidina, sinkonina dan sinkonidina (Sukasmono, 1980). Dari keempat alkaloid tersebut kinina dan kinidina yang mempunyai arti penting. Menurut Tjetje (1980), alkaloid kinina dapat digunakan sebagai obat malaria, anti kejang otot kaki dan kinidina sebagai obat denyut jantung yang tidak teratur (Cardiac Arytmic Depresant). Chinchona ledgerriana Moens, merupakan spesies kina yang banyak dibudidayakan di Indonesia, karena spesies ini memiliki mutu yang cukup baik dengan kadar kinina yang tinggi dibandingkan dengan spesies lainnya. Kadar kinina yang dikandung Chinchona ledgerriana Moens sebesar 7,5\%, sedangkan dalam jenis yang lainnya kurang dari 5\% (Sukasmono dan Santoso, 1988).

Perbanyakan tanaman kina dilakukan dengan cara vegetatif karena dapat dihasilkan dengan cepat dan tanamannya seragam. Menurut Setyawati (1993), cara pembiakan vegetatif dengan setek me- rupakan cara yang baik untuk mempertahankan sifat-sifat tanaman induknya. Melalui setek, pelaksanaan pembibitan cukup mudah dan cepat serta bahan seteknya mudah didapat.

Penanaman kina di Indonesia, biasa dilakukan dengan menggunakan bahan tanaman yang diperbanyak dengan semai sambung (grafted seedling) dan setek sambung (grafted cutting), yang pembuatannya memerlukan waktu yang relatif lama, yaitu 2,5 tahun untuk semai sambung dan satu tahun untuk setek sambung (Wibowo et al., 1990). Setek sambung pada tanaman kina menggunakan Cinchona ledgeriana atau ledger sebagai batang atas dan Cinchona succirubra atau succi sebagai batang bawah. Penggunaan kedua spesies yang berbeda ini dikarenakan kebutuhan akan sifat batang atas dan batang bawah yang berbeda (Sriyadi, 2006). Kedua penyambungan tersebut akan terjadi tanaman kina yang terdiri dari dua spesies. Bagian atas berkadar kinina tinggi tetapi perakarannya kurang baik, sedangkan bagian bawah berkadar kinina rendah tetapi perakarannya yang lebih baik. Selain bahan tanaman yang memenuhi syarat secara fisiologis juga ditentukan adanya zat pengatur tumbuh auksin yang berperan. Auksin adalah zat hormon tumbuhan yang ditemukan pada ujung batang, akar, dan pembentukan bunga, berperan penting dalam pertumbuhan tumbuhan. Menurut Weaver (1972) hubungan antara pertumbuhan dan kadar auksin sama pada akar, batang dan tunas yaitu auksin merangsang pertumbuhan 
pada kadar rendah, sebaliknya menghambat pertumbuhan pada kadar tinggi. Kadar optimum hormon untuk pertumbuhan akar jauh lebih rendah dari kadar optimum untuk pertumbuhan batang.

Sukasmono dan Santoso 1988), mengatakan bahwa pohon induk batang atas ledger dipilih dari klon unggul, pertumbuhan baik, tegak, tahan terhadap serangan hama atau penyakit, mudah menyesuaikan dengan lingkungan khususnya jenis tanah, berkadar kinina tinggi, dan mudah bertunas kembali setelah stumping. Klon-klon unggul anjuran antara lain adalah Cib 5, KP 105, KP 473-484 dan seri QRC. Klon QRC adalah generasi baru yang mempunyai keunggulan kadar kininanya dapat mencapat $15 \%$.

Setek sambung kina adalah bibit sambung kina yang terdiri dari batang bawah kina succi dengan batang atas kina ledger sebagai sambungannya. Batang bawah kina succi yang sering digunakan adalah semua bagian batang di bawah pucuk. Tetapi pada umumnya untuk metode sambung atau penyambungan dilapangan batang bawah yang digunakan adalah $5 \mathrm{~cm}-12 \mathrm{~cm}$ di atas pangkal tumbuhnya tunas.

Kematian setek sambung pada umumnya banyak juga disebabkan karena setek pucuk ledger yang digunakan terlalu muda. Berapakah panjang batang atas setek ledger yang optimum belum diketahui dengan baik, terutama untuk klon QRC. Oleh karena itu sangat penting untuk mengetahui berapa yang optimum panjang setek bagian atas atau ledger ini yang sesuai untuk bahan setek.

Penelitian ini dilakukan dengan tujuan untuk mempelajari pengaruh variasi panjang setek terhadap pertumbuhan setek sambung kina (Cinchona $s p$ ) klon QRC.

\section{BAHAN DAN METODE}

Penelitian dilaksanakan di kebun percobaan Pusat Penelitian Teh dan Kina (PPTK) Gambung, Kabupaten Bandung, dengan ketinggian kurang lebih 1300 meter di atas permukaan laut, jenis tanah Andisol, tipe iklim B menurut klasifikasi Schmidt dan Fergusson (1951) dengan curah hujan rata-rata antara 2000-3000 $\mathrm{mm}$ per tahun dan suhu rata-rata $13,5^{\circ} \mathrm{C}$ $21,1^{\circ} \mathrm{C}$. Kelembaban relatif antara $68 \%$ sampai $97 \%$.

Bahan untuk percobaan terdiri dari setek sambung atas kina (Cinchona ledgeriana Moens) klon QRC 203 yang diambil dari kebun induk gambung, setek batang bawah (Cinchona succirubra Pavon), polybag berukuran $12 \mathrm{~cm} \times 25 \mathrm{~cm}$, lapisan tanah atas (top soil) dan lapisan tanah (sub soil), fungisida Dithane M-45, Root-up (hormon perangsang pertumbuhan akar).

Alat yang digunakan adalah bambu, sungkup plastik, tali plastik $\mathrm{PE}$, hand sprayer, jolang, ember, pisau setek, gunting setek, penggaris, alat tulis dan lain-lain. Metode yang digunakan dalam penelitian ini adalah metode Eksperiment dengan Rancangan Acak Kelompok (RAK) yang terdiri dari 5 perlakuan dan diulang lima kali. Jumlah tanaman per plot adalah 50 tanaman, perlakuan panjang setek terdiri dari $5 \mathrm{~cm}, 7 \mathrm{~cm}, 9 \mathrm{~cm}, 11 \mathrm{~cm}$, dan $13 \mathrm{~cm}$.

Pembuatan setek sambung dilakukan dengan tahapan sebagai berikut :

1. Menyiapkan batang bawah Succi

Berasal dari batang muda atau tunastunas dari bekas tebangan, bukan dari 
cabang-cabang. Pohon induk yang baik dipilih dari pohon yang pertumbuhannya cepat dan mudah berakar dalam penyetekan. Batang atas diambil dari kebun kina yang berumur 5 tahun, bahan setek diambil dari setelah tunas berumur 8-12 bulan, mempunyai diameter sekitar 1 $\mathrm{cm}$, sehat dan bebas dari serangan hama penyakit. Batang bawah dipotong sepanjang sekitar $10 \mathrm{~cm}$, ujung atas dibelah sepanjang $2 \mathrm{~cm}$.

2. Menyiapkan batang atas ledger

Pohon induk yang siap diambil seteknya adalah yang berumur 3-5 tahun, karena daya regenerasinya cukup besar dan akan diperoleh bahan setek yang cukup banyak (Yoviana, 2014). Setek batang atas dipotong sepanjang $\pm 5 \mathrm{~cm}-7 \mathrm{~cm}$, dengan irisan meruncing ke bawah, irisan dibuat pada kedua sisinya (simetris). Semua daun dibuang sampai ke tangkai daun, kecuali pasangan daun ke 1 atau ke 2 setelah pucuk, daun yang ditinggalkan di potong 2/3-nya.

\section{Penyambungan}

Batang bawah Succi yang baik diambil dari bagian batang yang masih berair, berwarna coklat muda dan agak tua. Batang dipotong miring $40^{\circ}-60^{\circ}$ menjadi setek-setek dengan ukuran $10 \mathrm{~cm}$ dengan satu mata tunas. Bagian sisi ujung batang bawah dibelah sedalam $2 \mathrm{~cm}$ untuk menyelipkan batang atas. Batang atas diselipkan ke belahan batang bawah, Sambungan dibalut dengan tali plastik Poly Ethylene yang tipis $0,02 \mathrm{~mm}$ dan diikat. Cara mengikat tali dibuat sedemikian rupa agar tersusun rapat dan erat sehingga air siraman tidak masuk ke dalam luka sambungan. Ujung bawah stekres batang bawah dipotong meruncing dengan sudut $45^{\circ}$. Setek yang dipakai sepanjang 2 sampai 3 ruas dari pucuk. Setek sambung yang telah selesai disambung disimpan dalam ember yang telah diisi air yang sudah dicampur dengan Dithane M-45.

\section{Media Tanam}

Pembibitan setek sambung dilakukan pada polybag ukuran $12 \mathrm{~cm} \times 25 \mathrm{~cm}$ yang diberi lubang sebanyak 10 buah pada bagian samping dan satu buah pada bagian bawah dengan diameter $1 \mathrm{~cm}$. Topsoil yang telah dicampur dengan pupuk dan Dithane dimasukkan lebih dahulu ke dalam polybag sebanyak $2 / 3$ bagian. Selanjutnya diisi dengan tanah subsoil $1 / 3$ bagian sampai penuh.

\section{Penanaman Setek}

Polybag yang telah diatur di bedengan sehari sebelum penanaman setek sambung disiram dengan air bersih menggunakan emrat sampai jenuh. Stek sambung yang telah siap tanam ujungnya direndam dengan Root Up, kemudian ditanam pada polybag yang sebelumnya telah dibuat lubang tanam dengan tunggal kecil (ruju) sedalam $5 \mathrm{~cm}$, tanah sekitar setek sambung dipadatkan dengan jari agar kokoh dan tegak lurus. Selesai menanam bedengan disiram lagi dengan air secukupnya, kemudian ditutup dengan lembaran plastik sungkup diusahakan serapat mungkin sampai tidak ada yang bocor. Untuk mencegah serangan penyakit, tanah disemprot dengan lautan Dithane M-45 0,3\% menggunakan sprayer. Keadaan demikian dibiarkan sampai kurang lebih 3 bulan, sampai setek berakar. Setek tidak disiram sekurang-kurangnya sampai berumur 1 bulan, baru setelah itu disiram apabila tanah dalam polybag kering.
6. Pemeliharaan
Tanaman diberi pupuk daun setiap minggu atau urea $0,2 \%$. Penyiangan dilakukan menggunakan tangan, penyem- 
protan insektisida dilakukan jika ada serangan.

Variabel yang diamati adalah Persentase setek hidup (\%), pada umur 4,8 dan 12
Minggu Setelah Tanam (MST), Tinggi tanaman $(\mathrm{cm})$, Jumlah daun (bh), Jumlah akar (helai) dan Panjang akar $(\mathrm{cm})$ yang diamati pada umur 12 MST.
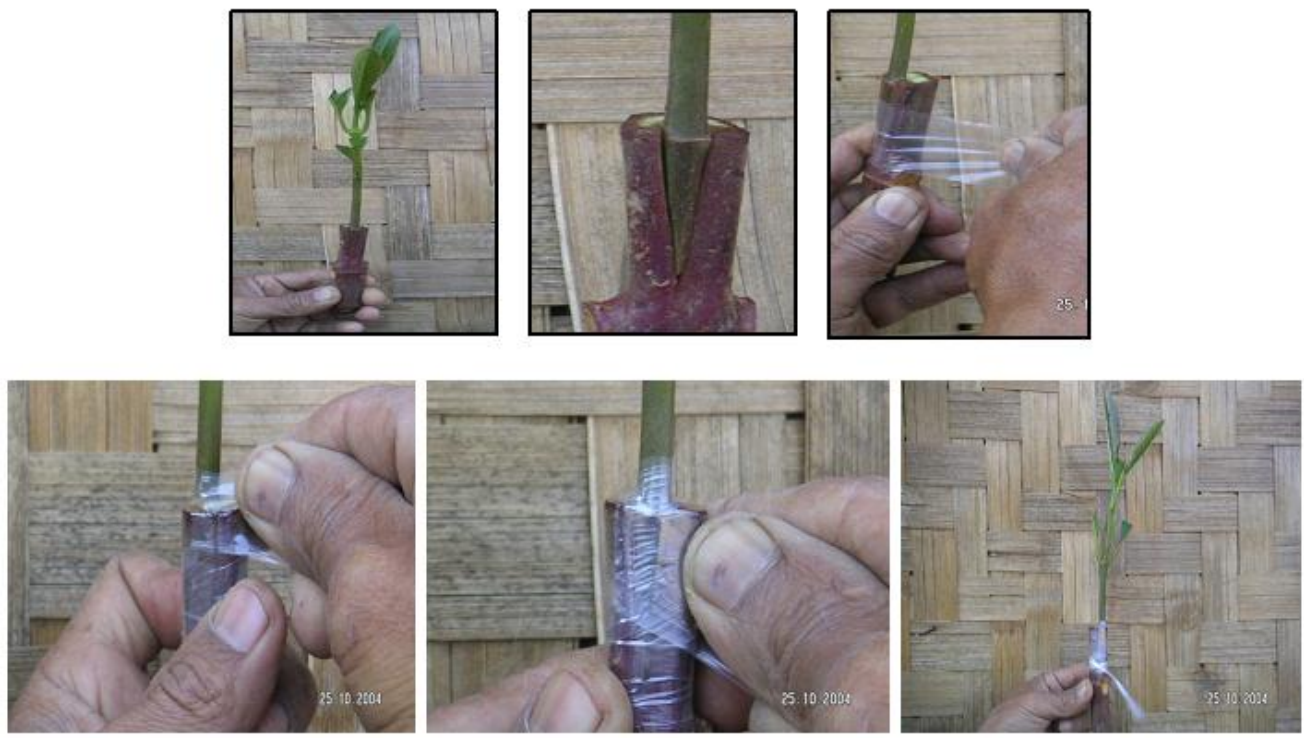

Gambar 1. Cara membuat setek sambung Kina Sumber : Tim PPTK, 2008.

\section{HASIL DAN PEMBAHASAN}

Variabel yang diamati pada penelitian ini adalah : persentase setek hidup, tinggi tanaman, jumlah daun, jumlah akar dan panjang akar.

\section{Persentase Setek Hidup}

Pengamatan terhadap persentase setek hidup dilakukan sebanyak 3 kali yaitu pada minggu ke 4, 8, dan 12 Minggu Setelah Tanam (MST). Terdapat variasi jumlah setek tumbuh dan berbeda nyata sampai umur 12 MST. hal ini diduga karena unsur hara yang tersedia sangat baik. Hasil ratarata persentase setek hidup tanaman disajikan pada Tabel 1 .

Tabel 1. Rata-rata persentase setek hidup pada umur 4, 8, dan 12 MST

\begin{tabular}{ccccc}
\hline Perlakuan Panjang Setek & \multicolumn{5}{c}{ Rata-Rata Persentase Setek hidup } \\
\cline { 2 - 5 } Atas & $4 \mathrm{MST}$ & $8 \mathrm{MST}$ & $12 \mathrm{MST}$ & $12 \mathrm{MST}$ \\
\hline & $49,60 \mathrm{~b}$ & $47,60 \mathrm{~b} \quad+\quad 35,40 \mathrm{a}$ & 70,80 \\
$\mathrm{~A}=5 \mathrm{~cm}$ & $48,60 \mathrm{~b}$ & $43,40 \mathrm{a}$ & $44,80 \mathrm{~b}$ & 89,60 \\
B $=7 \mathrm{~cm}$ & $47,80 \mathrm{ab}$ & $46,00 \mathrm{ab}$ & $40,60 \mathrm{~b}$ & 81,20 \\
$\mathrm{C}=9 \mathrm{~cm}$ & $48,60 \mathrm{~b}$ & $47,40 \mathrm{~b}$ & $45,40 \mathrm{c}$ & 90,80 \\
D = $11 \mathrm{~cm}$ & $46,00 \mathrm{a}$ & $43,60 \mathrm{a}$ & $41,80 \mathrm{bc}$ & 83,60 \\
E = $13 \mathrm{~cm}$ &
\end{tabular}

Keterangan :

- Angka rata-rata yang diikuti oleh huruf yang sama pada kolom yang sama menunjukkan hasil yang tidak berbeda nyata menurut Uji Jarak Berganda Duncan pada taraf $5 \%$.

- $\quad$ MST = Minggu Setelah Tanam. 
Tabel 1 menunjukkan bahwa pada umur 4 MST sampai dengan 8 MST semua perlakuan tidak memberikan pengaruh yang berbeda nyata terhadap persentase setek hidup di pembibitan. Pada akhir pengamatan (12 MST), persentase setek tumbuh berkisar antara 70,80\% - 90,80\%. Pada umur 12 MST, secara konsisten perlakuan $\mathrm{B}$ berbeda nyata dengan perlakuan lainnya dan memberikan persentase setek hidup terendah.

Persentase hidup tertinggi diperoleh pada perlakuan $\mathrm{D}$ yaitu panjang setek 11 $\mathrm{cm}$, namun perlakuan ini tidak berbeda nyata dengan perlakuan E. Hal tersebut mengindikasikan bahwa pada setek sambung kina tersebut telah terjadi pertautan yang sempurna antara kina succi sebagai batang bawah dan ledger sebagai batang atas.

Dalam mekanisme penyambungan ini Hartman dan Kester (1978), menyatakan bahwa tahap pertama pada peristiwa penyambungan yaitu terjadinya produksi jaringan kalus. Selanjutnya kalus akan berkembang dan berdiferensiasi menjadi sel-sel kambium baru, dengan demikian akan terjadi penggabungan antara dua kambium, yaitu kambium lama dan kambium dari batang bawah dan batang atas, hal ini sejalan dengan pendapat Abidin (1991), yang menyatakan bahwa graft union dibentuk dari penggabungan antara jaringan kalus dengan jaringan kambium baru.

Pertumbuhan dari setek sangat dipengaruhi oleh ketersediaan bahan makanan dari setek yang digunakan. Pemakaian panjang setek $11 \mathrm{~cm}$ dan $13 \mathrm{~cm}$ ternyata mampu mendukung pertumbuhan dari bibit kina. Ketersediaan bahan makanan berupa karbohidrat dan nitrogen yang terkandung dalam bahan setek yang digunakan cukup untuk menumbuhkan bibit kina.

Kondisi pertumbuhan setek cukup baik, hal ini diduga kondisi persedian fotosintat pada sel (karbohidrat) masih optimum untuk pertumbuhan setek namun ada sebagian kecil setek yang mengalami kematian atau mengering dikarenakan gagalnya setek dalam tahap inisiasi perakaran (Febriana, 2009). Ditambahakan oleh Hartmann dan Kester (1978) bahwa bahan setek yang mengandung karbohidrat tinggi dan nitrogen cukup akan membentuk akar dan tunas.

\section{Tinggi bibit, Jumlah daun, Jumlah akar dan Panjang akar}

Hasil pengamatan terhadap tinggi bibit, jumlah daun, jumlah akar dan panjang akar disajikan pada Tabel 2 .

Tabel 2. Rata-rata tinggi bibit, jumlah daun, jumlah akar, dan panjang akar pada umur 12 MST

\begin{tabular}{|c|c|c|c|c|}
\hline \multirow[b]{2}{*}{ Perlakuan } & \multicolumn{4}{|c|}{ Rata-rata pengamatan pada umur bibit 12 MST } \\
\hline & Tinggi bibit & Jumlah daun & $\begin{array}{c}\text { Jumlah } \\
\text { Akar }\end{array}$ & $\begin{array}{c}\text { Panjang } \\
\text { Akar }\end{array}$ \\
\hline & $--\mathrm{cm}--$ & & & $--\mathrm{cm}--$ \\
\hline$A=5 \mathrm{~cm}$ & $23,94 a b$ & $19,00 \mathrm{c}$ & 23,80 a & $10,00 \mathrm{a}$ \\
\hline$B=7 \mathrm{~cm}$ & $28,66 \mathrm{~b}$ & $16,00 \mathrm{abc}$ & $29,20 \mathrm{a}$ & $10,80 \mathrm{a}$ \\
\hline$C=9 \mathrm{~cm}$ & $23,60 \mathrm{ab}$ & $17,80 \mathrm{bc}$ & 27,20 a & $10,60 \mathrm{a}$ \\
\hline $\mathrm{D}=11 \mathrm{~cm}$ & 19,02 a & $15,20 a b$ & 25,80 a & $12,40 \mathrm{a}$ \\
\hline$E=13 \mathrm{~cm}$ & 18,34 a & 13,60 a & 29,80 a & $12,40 \mathrm{a}$ \\
\hline
\end{tabular}

Keterangan :

- $\quad$ Angka rata-rata yang diikuti oleh huruf yang sama pada kolom yang sama menunjukkan hasil yang tidak berbeda nyata menurut Uji Jarak Berganda Duncan pada taraf $5 \%$.

- $\quad$ MST = Minggu Setelah Tanam. 


\section{Tinggi Tanaman}

Pengaruh perlakuan terhadap tinggi tanaman pada umur 12 MST menunjukkan bahwa perlakuan B $(7 \mathrm{~cm})$ memberikan pengaruh yang paling baik dengan tinggi bibit $28,66 \mathrm{~cm}$ dibandingkan perlakuan $\mathrm{D}=$ $11 \mathrm{~cm}$ dan $\mathrm{E}=13 \mathrm{~cm}$ tetapi tidak berbeda nyata dengan perlakuan $A=5 \mathrm{~cm}$ dan $\mathrm{C}=$ $9 \mathrm{~cm}$.

Tinggi tanaman merupakan parameter yang sangat penting karena mencerminkan kemampuan tanaman untuk tumbuh dan membentuk jaringan muda dari bagian tanaman dan menentukan dalam pembentukan karbohidrat sebagai makanan cadangan.

Karbohidrat merupakan hasil utama dari hasil fotosintesis yang memegang peranan penting dalam pertumbuhan tanaman, karena karbohidrat merupakan bahan penyusun utama berbagai proses dalam tubuh tanaman, sehingga jika tanaman kekurangan karbohidrat pertumbuhan tanaman akan terhambat.

\section{Jumlah daun}

Pengamatan terhadap jumlah daun pada minggu 12 setelah tanam menunjukkan keragaman jumlah daun dari variasi perlakuan panjang setek. Hasil rata-rata jumlah daun tersebut dapat dilihat pada Tabel 2. Perlakuan $A=5 \mathrm{~cm}$ memberikan hasil rata-rata jumlah daun terbanyak yaitu 19 helai daun tiap bibit dibandingkan dengan perlakuan $D$, tetapi tidak berbeda nyata dengan perlakuan B dan C. Hal ini menunjukkan bahwa tunas-tunas aktif lebih cepat membentuk tunas-tunas baru yang menjadi daun dibandingkan perlakuan lainnya sehingga terbentuknya daun pada setek yang lebih pendek lebih cepat pertumbuhan daun-daun mudanya.

Pertambahan jumlah daun mempunyai peranan penting dalam proses asimilasi. Daun pada setek tanaman menentukan kelangsungan hidup suatu tanaman, karena di dalam daun terjadi proses fotosintesis, respirasi dan transpirasi (Abidin, 1991).

\section{Jumlah Akar}

Rata-rata jumlah akar tiap bibit dari seluruh perlakuan yang dicoba menunjukkan tidak berbeda nyata pada umur bibit $12 \mathrm{MST}$, baik perlakuan A, B, C, D dan E. Jumlah akar berkisar antara 23,80 helai pada perlakuan A sampai dengan 29,80 helai pada perlakuan $E$ yang terbanyak sedangkan perlakuan B nilainya berdekatan dengan perlakuan $E$, yaitu 29,20 helai.

Pembentukan akar memerlukan kematangan fisiologis dari setek dan tersedianya zat pengatur tumbuh yang dapat mempercepat terbentuknya akar. Bahan setek yang paling panjang kematangan fisiologis lebih baik dibandingkan setek yang lebih pendek karena lebih sukulen yang umumnya lebih lama terbentuknya kalus dan cahaya yang cukup. Hal ini sejalan dengan pernyataan Rochiman dan Sri (1973) bahwa pembentukan akar biasanya didahului oleh pembentukan kalus, tetapi adanya kalus bukan merupakan tanda bahwa setek pasti dapat menghasilkan akar. Walaupun pembentukan akar setek tidak hanya tergantung pada terbentuknya kalus, tetapi akar yang keluar dari jaringan akan lebih kuat dan lebih baik dari pada akar yang keluar dari setek yang tidak berkalus.

Stoutmeyer dalam Hartman dan Kester (1978), menyatakan bahwa intensitas cahaya yang rendah sangat baik untuk pembentukan akar. Akar-akar yang terbentuk pada setek dipengaruhi oleh interaksi yang kompleks antara faktorfaktor endogen dan lingkungan. Menurut Weaver (1972), semakin tinggi kandungan auksin setek pada saat pengambilan, maka akan semakin banyak jumlah akar yang tumbuh.

\section{Panjang Akar}

Tumbuhnya akar merupakan salah satu indikasi dari keberhasilan stek yang dilakukan karena akar memegang peranan penting bagi tanaman. Fungsi dari akar yaitu menyerap air dan mineral terlarut, transportasi unsur hara, pengokoh batang, dan penyimpan cadangan makanan. 
Semakin panjang akar yang terbentuk semakin memudahkan tanaman dalam menjalankan fungsinya, salah satunya dalam penyerapan unsur hara.

Pengamatan terhadap panjang akar dilakukan sebanyak 1 kali yaitu pada minggu ke 12 setelah tanam, hasilnya sebagimana disajikan pada Tabel 2 . Sebagaimana halnya pada pengamatan jumlah akar, hasil pengukuran terhadap semua perlakuan tidak menunjukkan perbedaan yang nyata. Bila ditelaah nilai panjang akarnya pada perlakuan $\mathrm{D}$ dan $\mathrm{E}$ menunjukkan rata-rata yang sama yaitu $12,40 \mathrm{~cm}$.

Sebagaimana ditunjukkan pada parameter jumlah akar di atas, pada perlakuan setek yang lebih panjang dengan kematangan fisiologis bahan setek yang optimal memberikan jumlah akar yang lebih banyak dan panjang, hal ini dapat dipahami oleh karena inisiasi perakaran yang lebih cepat akan memberikan pertumbuhan akar yang lebih cepat atau lebih panjang juga oleh dorongan kandungan auksin di dalamnya. Prawiranata et al., (1981) mengatakan bahwa jaringan tanaman di dalam setek tersebut sudah mengandung senyawa yang penting untuk pembentukan auksin, sehingga bila setek ditanam akar akan cepat terbentuk.

Akar pada setek terbentuk secara adventif dari kambium dan bagian node (buku). Akar pada setek terbentuk karena pelukaan, dan akar terbentuk dari jaringan parenchym (Moko, 2004). Keberhasilan setek dicirikan oleh didapatnya bibit yang memiliki perakaran dan pertumbuhan yang baik dalam jumlah yang banyak pada satuan waktu tertentu (Pranoto, 1986).

Pertumbuhan dan perkembangan akar dipengaruhi oleh kandungan bahan setek yang digunakan terutama persediaan dari karbohidrat dan nitrogen. Menurut Hartmaan dan Kester (1978), setek yang mengandung karbohidrat yang tinggi dan nitrogen yang cukup akan membentuk akar dan tunas. Semakin panjang setek yang digunakan maka pertumbuhan panjang akarnya semakin baik karena lebih banyak cadangan makanan yang digunakan untuk mendukung pertumbuhan akarnya.

Ditambahkan oleh Magingo et al., (2001), bahwa pertumbuhan akar pada setek batang dipengaruhi oleh kandungan karbohidrat dan panjang setek. Semakin panjang setek yang digunakan maka pertumbuhan panjang akarnya semakin baik karena lebih banyak cadangan makanan yang digunakan untuk mendukung pertumbuhan akarnya.

\section{SIMPULAN}

Berdasarkan penelitian yang telah dilakukan maka dapat disimpulkan, yaitu :

a. Panjang setek sambung atas yang berbeda memberikan pengaruh yang berbeda terhadap persentase setek hidup, panjang setek, jumlah daun, jumlah akar dan panjang akar bibit kina di pembibitan.

b. Penggunaan setek sambung dengan panjang $7 \mathrm{~cm}$, memberikan pengaruh yang paling baik terhadap pertumbuhan bibit sambung kina (Cinchona ledgeriana Moens) di pembibitan yang ditunjukkan oleh persentase hidup, tinggi bibit, jumlah daun dan jumlah akar yang lebih tinggi dibanding perlakuan yang lain.

\section{DAFTAR PUSTAKA}

Abidin, Z. 1991. Dasar Pengetahuan IImu Tanaman. Penerbit Angkasa. Bandung. 177p.

Edmond, J. B., T. L. Seen, F. S. Amdrews and R. G. Halfacre 1983. Fundamental of Horticulture. Tata Mc Graw Hill Book Co Ltd, New Delhi. 560p.

Febriana, S. 2009. Pengaruh Konsentrasi ZPT dan Panjang Setek terhadap Pembentukan Akar dan Tunas pada Setek Apokad (Persea americana 
Mill). Skripsi; Institut Pertanian Bogor. Bogor.

Hartman, H. T. and D. E. Kester. 1978. Plant Progpagation. Third ed. Prentice Hall of India Private Ltd.

Koesriningrum, Rochiman dan Sri Setyati Harjadi, 1973. Pembiakan vegetative. Dept. Agronomi Fakultas Pertanian Institute Pertanian Bogor.

Magingo, F.S.S. and J.Dick, J.M.C.P. 2001. Propagation of Two Miombo Woodland Trees by Leafy Stem Cuttings Obtained from Seedlings. Agroforestry Systems 51: p. 49-55.

Moko, H. 2004. Teknik Perbanyakan Tanaman Hutan Secara Vegetative. Informasi Teknis 2(1): hal. 1-20.

Pranoto, C. 1986. Pengaruh Pemberiaan IBA dan Campuran IBA-NAA Terhadap Keberhasilan Stek Cemara Kipas (Thuja orientalis L.). Laporan Karya Ilmiah. Fakultas Pertanian. Institut Pertanian Bogor. Bogor.

Rochiman, K dan Sri Setyadi Haryadi. 1973. Pembiakan Vegetatif. Departemen Agronomi Fakultas pertanian. IPB. Bogor. 72p.

Schmidt, F.H and J.A.H. Ferguson. 1951. Rainfall Type Based Wet and Dry Period Rations for Indonesia With Western New Guinea. Kementerian Perhubungan Jawatan Meteorologi dan Geofisika. Verhandeling, Jakarta.

Setyawati. 1993. Pengaruh Kombinasi Hormon Tumbuh Alami dan pupuk Daun terhadap Pertumbuhan Setek Pucuk Kina Ledger (Cinchona ledgeriana Moens).
Sriyadi. 2006. Komunikasi Pribadi. Pusat Penelitian Teh dan Kina Gambung. Bandung.

Sukasmono. 1980. Pembiakan Kina dan Setek. Risalah Simposium Kina Ketiga. BPTK, Gambung, Bandung. 111-116 p.

dan Santoso, J. 1988. Tuntunan Budidaya Kina. Balai Penelitian Teh dan Kina. Gambung. 70 hal.

Tim PPTK, 2008. Petunjuk Teknis Budidaya Tanaman Kina. Pusat Penelitian Teh dan Kina, Gambung, Bandung

Tjetje. 1980. Tinjauan terhadap Pemasaran Kina. Warta BPTK (6/2) : 11-23

Prawiranata, S., Harran dan P. Tjondronegoro. 1981. Dasar-dasar Fisiologis Tumbuhan. Jilid II. Departemen Botani Fakultas Pertanian IPB, Bogor.

Weaver, R.J. 1972. Plant Growth Substance in Agriculture W. H. Freeman and Company. San Farnisco.

Wibowo, S, Santoso, J. dan Sukasmono. 1990. Pengaruh Panjang Bahan Setek dan Kadar Rootone $F$ terhadap Pertumbuhan Setek Pucuk Kina (Cinchona ledgeriana) Klon QRC. Warta teh dan Kina I $(1 / 2 / 3): 49-54$

Yoviana, E.A. 2014. Perbanyakan Kina dengan Setek Sambung. http://ditjenbun.pertanian.go.id/ta nregar/berita-271-perbanyakankina-dengan-setek-sambung.html. Diakses 19 Maret 2016. 